\title{
Forcing the Bystander to Get Involved: A Case for a Statute Requiring Witnesses to Report Crime
}

Criminal activity is continuing at an alarming rate in the United States, ${ }^{1}$ causing widespread fear ${ }^{2}$ and changing how people live their lives. ${ }^{3}$ Although some citizens assist the police in combatting crime, ${ }^{4}$ the majority of crime goes unreported, ${ }^{5}$ severely hampering the efforts of the police. ${ }^{6}$ Without prompt crime reporting by citizens, the chance of apprehending criminals diminishes significantly. ${ }^{7}$

Commentators have proposed to increase citizen involvement in all emergencies, both criminal and noncriminal, through the imposition of an affirmative duty to rescue. ${ }^{8}$ While such a duty may be appropriate in

1. Nearly a third of all American households were victimized by serious crime in 1981. BUREAU of Justice Statistics, U.S. Dep't of Justice, Report to the Nation On Grime and JusTICE 7 (1983) [hereinafter cited as REPORT].

2. More than $60 \%$ of residents in large cities fear walking outside at night. See W. Skogan \& M. Maxfield, Coping with Crime: Individual and Neighborhood Reactions 47 (1981).

3. Forty-five percent of urban residents limit personal activity because they fear crime. See J. Garofalo, Public Opinion about Crime: The Attitudes of Victims and Nonvictims in Selected CrTies 76 (1977).

4. For example, some cities have established "neighborhood watch" or "block watcher" crime reporting programs which, in certain instances, have produced dramatic crime reductions. Crim. Just. Newsletter, Feb. 28, 1983, at 6.

5. Particularly tragic cases, like that of Catherine Genovese, provide anecdotal evidence of the severity of the problem of witness' failure to report crimes. On March 13, 1964, Ms. Genovese was viciously attacked and killed while 38 of her neighbors failed to call the police from the safety of their apartments. See A. Rosenthal, ThIRTY-Eight Witnesses 29-30 (1964). Official estimates indicate that only $47 \%$ of violent crimes and only one third of all crimes are reported to the police. REPORT, supra note 1 , at 24-25. Some research has found underreporting to be less severe than suggested by government statistics. See Myers, Why Are Crimes Underreported? What is the Crime Rate? Does it Really Matter?, 61 Soc. ScI. Q. 23, 32-33 (1980) (mathematical adjustment of Uniform Crime Statistics yielded $10 \%$ increase over official national reporting rate estimates), while experiments involving staged crimes show reporting rates as low as six or seven percent. Bickman \& Green, Situational Cues and Crime Reporting: Do Signs Make a Difference?, 7 J. APPLIED Soc. Psychology 1, 8 (1977); Dertke, Penner \& Ulrich, Observer's Reporting of Shoplifting as a Function of Thiefs Race and Sex, 94 J. Soc. Psycholocy 213, 217 (1974).

6. The proportion of crime directly discovered by the police may be less than six percent. See Mawby, Witnessing Crime Toward a Model of Public Intervention, 7 CRm. Jusr. \& Berav. 437, 443 (1980); see also Black, Production of Crime Rates, 35 AM. Soc. REv. 733, 735 (1970) (vast majority of crime known to police by citizen reports rather than proactive police efforts).

7. The probability of arrest for a crime reported in progress is $33 \%$. A mere fifteen-minute delay in reporting reduces this probability to $5 \%$. REPORT, supra note 1 , at 51 .

8. See, e.g., Rudolph, The Duty to Act: A Proposed Rule, 44 NEB. L. REv. 499, 509 (1965) (proposing duty to act when harm or loss is imminent and costs of acting are less than harm to be avoided); Scheid, Affirmative Duty to Act in Emergency Situations-The Return of the Good Samaritan, 3 J. MÀr. J. Prac. \& Proc. 1, 16 (1969) (proposing duty to act in order to prevent death or serious bodily harm when no personal risk to rescuer); Weinrib, The Case for a Duty to Rescue, 90 YALE L.J. 247 (1980) (proposing duty of "easy rescue," requiring action to remedy dangerous situa- 
some emergencies, it would be unwise to impose it in the criminal context, because of the danger of vigilantism. ${ }^{9}$ As an alternative, this Note proposes the enactment of a criminal statute mandating the reporting of felonies directly witnessed by citizens.

\section{Factors Associated with the Failure to Report Grime}

In recent years, social psychology researchers have attempted to provide scientific explanations for the lack of bystander intervention in emergencies $^{10}$ and the underreporting of crime. Rather than attributing bystander inaction to callousness or selfishness, their work points to significant sociological and psychological factors ${ }^{11}$ that affect such behavior. Chief among these factors is diffusion of responsibility. The presence of several or more bystanders diffuses individual responsibility and blame for not helping among the group, thereby serving both to reduce ${ }^{12}$ and to

tion when no significant cost to rescuer); Woozley, $A$ Duty to Rescue: Some Thoughts on Criminal Liability, 69 VA. L. REv. 1273 (1983) (proposing criminal sanctions for those who fail to attempt to assist others in physical danger).

9. For the purposes of this Note, "vigilantism" refers to self-help actions by citizens that tend to disrupt the administration of the criminal justice system.

10. The research of social-psychologists who have studied emergency intervention is highly relevant in explaining crime reporting behavior for two reasons. First, many of these experiments have involved staged criminal events. See, e.g., Moriarty, Crime, Commitment, and the Responsive Bystander: Two Field Experiments, 31 J. Personalrty \& Soc. Psychology 370 (1975) (staged thefts); Schwartz \& Gottlieb, Bystander Anonymity and Reactions to Emergencies, 39 J. PersonaLITY \& Soc. Psychology 418 (1980) (simulated robbery employing physical force); Shotland \& Stebbins, Bystander Response to Rape: Can a Victim Attract Help?, $10 \mathrm{~J}$. ApPLIED Soc. PsYchology 510 (1980) (auditory simulation of forcible rape).

Second, one of the primary options open to subjects in these experiments, be they criminal or noncriminal situations, is to report the staged event to an authority figure, such as the experimenter or victim. See, e.g., Darley, \& Latané, Bystander Intervention in Emergencies: Diffusion of Responsibility, 8 J. Personality \& Soc. Psychology 377 (1968) (opportunity to report seizure to experimenter), Moriarty, supra (opportunity to report theft to victim); Schwartz \& Gottlieb, supra (opportunity to telephone experimenter to report robbery). Thus, these intervention experiments have explored the dynamics of behavior that surround summoning assistance and reporting unusual events.

11. The factors described in this Note certainly do not exhaust all of the possible sociological, psychological or other explanations for bystander behavior. See infra note 113. Nor would all of the social-psychologists who are conducting research in this area agree with the use of the labels this Note employs for the theories they describe. See Schwartz \& Gottlieb, Bystander Reactions to a Violent Theft: Crime in Jerusalem, $34 \mathrm{~J}$. Personalrty \& Soc. Psychology 1188 (1976) (claiming that other research on bystander intervention in emergencies has confused and mislabeled underlying processes involved).

12. See, e.g., Korte, Effects of Individual Responsibility and Group Communication on Helpgiving in an Emergency, 24 HuM. ReL. 149, 154 (1971); Latané \& Rodin, A Lady in Distress: Inhibiting Effects of Friends and Strangers on Bystander Intervention, 5 J. ExP. Soc. Psycholocy 189, 193 (1969); Shaffer, Rogel \& Hendrick, Intervention in the Library: The Effect of Increased Responsibility on Bystanders' Willingness to Prevent a Theft, 5 J. APPLIEn Soc. Psychology 303, 315 (1975). But see Piliavin \& Rodin, Good Samaritanism: An Underground Phenomenon?, $13 \mathrm{~J}$. PersonaltTy \& Soc. Psychology 289, 296-97 (1969) (effects of diffusion of responsibility may be outweighed by increased probability that at least one bystander will render assistance when number of bystanders increases); Yinon, Sharon, Gonen \& Adom, Escape From Responsibility and Help in Emergencies Among Persons Alone or Within Groups, 12 EuR. J. Soc. Psxchology 301, 303 (1982) (increased number of bystanders more likely to report suspicious package). 
delay ${ }^{13}$ intervention, at times resulting in inaction by all. ${ }^{14}$ Indeed, the effects of diffusion of responsibility may be more pronounced in the area of crime reporting because bystanders tend to place the responsibility for the control of criminal activity on specific groups in the population, such as the police or politicians.

Closely related to diffusion of responsibility is the tendency of individual behavior to be influenced by the behavior and expectations of others. Bystander behavior reflects this "social influence" in a number of ways. First, the behavior of others serves as a model for bystanders. Thus, the inaction of other witnesses may encourage an individual bystander to do nothing, ${ }^{15}$ while positive social influence may encourage certain bystander behavior. Research has found that verbal encouragement ${ }^{16}$ and interpersonal influence ${ }^{17}$ can increase crime reporting. Second, bystanders sometimes perceive that others are evaluating their reactions and behavior in response to an emergency or crime. Galling this concern "evaluation apprehension,"18 researchers have theorized that an anonymous bystander who is immune from negative evaluations is less likely to intervene than one who is not. ${ }^{19}$ Thus, the underreporting of crime may be due in part to a lack of perceived social pressure. Finally, social norms play a role in encouraging bystander behavior. For example, the norm of male assertiveness may encourage intervention by males, particularly when in the presence of females. ${ }^{20}$ Contrary to the theory of diffusion of responsibility, some researchers have postulated the existence of a "norm of social responsibility," reinforced by the presence of additional bystanders, which encourages helpful behavior. ${ }^{21}$

Another factor affecting bystander reactions is the immobilization that occurs due to indecision. Onlookers' failure to intervene is not the result of a conscious decision but rather due to an unresolved internal conflict concerning whether to act, and what course of action to take. ${ }^{22}$ This indeci-

13. See, e.g., Schwartz \& Clausen, Responsibility, Norms, and Helping in an Emergency, $16 \mathrm{~J}$. Personality \& Soc. Psychology 299, 304 (1970) (lone bystanders respond faster); Schwartz \& Gottlieb, supra note 10, at 425 (same); Schwartz \& Gottlieb, supra note 11, at 1194 (same).

14. See Darley \& Latané, supra note 10 , at 377.

15. See Darley, Teger \& Lewis, Do Groups Always Inhibit Individuals' Responses to Potential Emergencies, 26 J. PersonalrTy \& Soc. Psychology 395 (1973) (discussing pluralistic ignorance; bystanders conform to passive nonhelping behavior of others); Latané \& Rodin supra, note 12, at 193 (unresponsive bystanders inhibited helping by others).

16. See Bickman \& Rosenbaum, Crime Reporting as a Function of Bystander Encouragement, Surveillance and Credibility, 35 J. PersonalrTy \& Soc. Psychology 577, 580 (1977) (verbal encouragement of stranger found to increase reporting of shoplifting).

17. Bickman \& Green, supra note 5, at 14-15.

18. Schwartz \& Gottlieb, supra note 10, at 418-19.

19. Id. at 419.

20. See Schwartz \& Clausen, supra note 13, at 307.

21. Yinon, Sharon, Gonen \& Adom, supra note 12 , at 304.

22. B. Latane \& J. Darley, The Unresponsive Bystander: Why Doesn't He Heip? 
sion stems from the lack of information available to the bystander. Observing a crime or an accident is a rare occurrence for most people. ${ }^{23} \mathrm{~A}$ witness must first decide whether an emergency that requires intervention, ${ }^{24}$ is in fact occurring and then determine a proper response. The more ambiguous the accident or crime, the less likely it is that bystanders will intervene or even report the situation. ${ }^{25}$ Even if a witness determines that an event is a serious accident or crime, indecision over what type of intervention is necessary may result in a complete failure to act. Once informed of the proper course of action, however, a bystander is more likely to intervene. ${ }^{28}$

Others in the field have proposed a cost-benefit model of crime reporting or bystander intervention, ${ }^{27}$ suggesting that the bystander weighs the costs and benefits of reporting and then acts accordingly. The bystander will take into account both psychological costs such as guilt, ${ }^{28}$ and more tangible ones, such as possible legal repercussions ${ }^{29}$ or physical reprisal by the criminal..$^{30}$

In fact, all of the social and psychological factors discussed above interact with one another to produce a net effect on crime reporting or bystander intervention. For example, diffusion of responsibility may lower the social costs to individual bystanders of not helping, making it easier

31-36 (1970). (describing the many decisions bystander must make quickly when confronted with emergency situation).

23. Even police rarely witness a crime. See Bickman, Bystander Intervention in a Crime, in Victims AND SocieTY 144, 145 (1976) (average Los Angeles police officer directly witnesses robbery only once in 14 years).

24. See Shotland \& Huston, Emergencies: What Are They and Do They Influence Bystanders to Intervene?, 37 J. Personality \& Soc. Psychology 1822 (1979) (attempting to define characteristics of an emergency, noting that bystanders more likely to intervene when they perceive increasing threat of harm to victim).

25. See Clark \& Word, Where is the Apathetic Bystander? Situational Characteristics of the Emergency, 29 J. Personality \& Soc. Psychology 279 (1974) (possible electrocution of worker; less help when ambiguity surrounds accident); Clark \& Word, Why Don't Bystanders Help? Because of Ambiguity?, 24 J. Personality \& SOC. Psychology 392 (1972) (maintenance worker falling from ladder; less help in ambiguous situation); Shotland \& Stebbins, supra note 10, at 521-22 (bystanders reluctant to take action upon hearing simulated rape because of uncertainty about what was happening).

26. See Schwartz \& Clausen, supra note 13 , at 305 .

27. Bleda, Bleda, Byrne \& White, When a Bystander Becomes an Accomplice: Situational Determinants of Reactions to Dishonesty, 12 J. Experimental Soc. Psychology 9, 23 (1976); Kidd, Crime Reporting: Toward a Social Psychological Model, 17 CRIMINolocy 380 (1979); Piliavin \& Rodin, supra note 12 , at 298.

28. Shaffer, Rogel \& Hendrick, supra note 12, at 317.

29. See Gelfand, Hartman, Walder \& Page, Who Reports Shoplifters? A Field-Experimental Study, 25 J. Personaltry \& Soc. Psychology 276, 283 (1973) (41\% of subjects who failed to report shoplifting stated as reason either fear of a countersuit for false accusation or demands of a court appearance) [hereinafter cited as Gelfand].

30. Fear of physical reprisal may be a rare cause of not reporting crime. According to the Department of Justice, it was a reason for failure to report in only one percent of personal crimes. BuREAU of Justice Statistics, U.S. DeP'T of Justice, Criminal Victimization in the United STATES, 1981, at 75, table 100 (1983). 
for them to fail to act. ${ }^{91}$ The labels are assigned only to make some sense out of the dynamics that underly a complex behavior.

\section{Common law Attempt to Address the Problem of Witness FaIluRe to Report CRIME}

Any serious consideration of the issues surrounding the reporting of crime must include a discussion of the common law offense of misprision of felony. Such a discussion is, however, complicated by the fact that it is unclear what the offense is ${ }^{32}$ or, more fundamentally, whether it now exists or has ever existed. . $^{33}$

Under English law, the common law offense, now legislatively abolished, ${ }^{34}$ had an uncertain definition. In Sykes $v$. Director of Public Prosecutions, ${ }^{36}$ Lord Denning held that misprision of felony had always existed in the common law of England ${ }^{36}$ and that it consisted of knowledge that a felony had been committed and a failure to disclose it. ${ }^{37}$ In fact, however, English courts seemed to require some role in the crime, not simply a mere passive failure to report it. ${ }^{38}$

31. Howard \& Crano, Effect of Sex, Conversation, Location, and Size of Observer Group on Bystander Intervention in a High Risk Situation, 37 SociomeTry 491, 504 (1974) (staged theft).

32. E.g., Howard, Misprisions, Compoundings and Compromises, 1959 GRIM. L. Rev. 750 ("A short description might run as follows: misprision of felony is the misdemeanour of failing to communicate to the proper authority one's knowledge of the commission of a felony; but this apparently simple statement bristles with uncertainties.").

33. E.g., W. Lafave \& A. ScotT, Criminal Law 526 (1972) ("It is doubtful whether this offense ever had a meaningful existence beyond the textbook writers. The offense was said to be 'practically obsolete' in England almost a century ago. . . . Doubt has been expressed as to whether this offense was ever inherited by the United States as a part of the common law.") (footnotes omitted).

34. See Comment, Misprision of Felony: A Reappraisal, 23 Emory L.J. 1095, 1100-01 nn.35 \& 36 (1974).

35. [1962] A.C. 528.

36. There is an extensive debate as to whether misprision of felony did indeed have a historical foundation in English common law. Glazebrook, in an exhaustive examination of English history, concludes that the offense never really existed but was the result of an accident in interpretation. See Glazebrook, Misprision of Felony-Shadow or Phantom? (pts. 1 \& 2), 8 AM. J. LEGAL Hisr. 189 \& 283 (1964). Other commentators who have examined the English precedents have concluded otherwise. See Allen, Misprision, 78 LAw Q. REv. 40, 51-52 (1962); Comment, supra note 34, 1096-98; Recent Cases, 8 U. CHI. L. Rev. 338, 340-41 (1941).

37. The immediate reaction to the Sykes decision was negative; commentators considered the offense too vague and broad in its announced form. See Allen, supra note 36, at 55-61; Glazebrook, How Long, Then, Is the Arm of the Law to Be?, 25 MoD. L. REv. 301 (1962). Later commentators have been more receptive of the offense, albeit in modified form. See Comment, supra note 34, at 1112-17 (recommending limiting offense to small class of felonies and imposing duty only on public officers); Cases Noted, Misprision of Felony: A Crime Whose Time Has Come, Again, 28 U. FuA. L. REv. 199, 212-13 (1975) (advocating establishing exception for family members and limiting class of felonies). Other commentators are divided. See Goldberg, Misprision of Felony: An Old Concept in $a$ New Context, 52 A.B.A.J. 148 (1966) (recommending retention of crime in Sykes form); Comment, Misprision of Felony Not a Crime in Florida, 30 U. MIAMI L. REv. 222, 229 (1975) (favoring retention of original common law offense); Recent Cases, 54 Harv. L. Rev. 506 (1941) (urging rejection of offense); Recent Decisions, 32 VA. L. Rev. 170 (1945) (same).

38. English courts have applied misprision of felony only in those cases where the defendant was 
In the United States, the offense is also only vaguely defined. At the federal level there has long been a misprision of felony statute, ${ }^{39}$ which requires persons to make felonies known to an appropriate United States authority. Despite the statute's broad language, a mere failure to report is not sufficient for a conviction. Federal courts uniformly require an affirmative act of concealment to complete this crime. ${ }^{40}$

With few exceptions, ${ }^{41}$ modern state courts and legislatures have entirely rejected the existence of a common law misprision of felony offense as incompatible with modern society. ${ }^{42}$ It is not clear what the crime required at the state level. One common definition of the offense was that stated by the Supreme Court of Vermont:

Misprision of felony is an offense at common law, and is described as a criminal neglect either to prevent a felony from being committed or to bring the offender to justice after its commission, but without such previous concert with or subsequent assistance of him as will make the concealer an accessory before or after the fact. ${ }^{43}$

Other precedent supported the notion that the offense consisted of fail-

not a mere bystander, but had some role in the crime itself. See, e.g., Lucraft, 50 Crim. App. 296 (1966) (defendant helped count money from robbery); Regina v. King [1965] 1 W.L.R. 706 (defendant hired car used by others in robbery); Sykes, [1962] A.C. 528, (defendant approached waiter asking if he was an I.R.A. contact who could help others sell stolen firearms). It appears, therefore, that the English misprision of felony offense is designed to fill the void, punishing those persons who have not done quite enough in furtherance of the crime to be considered an accessory after the fact, but have nevertheless become involved with the underlying offense.

39. 18 U.S.C. $\$ 4$ (1982) ("Whoever, having knowledge of the actual commission of a felony cognizable by a court of the United States, conceals and does not as soon as possible make known the same to some judge or other person in civil or military authority under the United States, shall be fined not more than $\$ 500$ or imprisoned not more than three years, or both.").

40. See, e.g., United States v. Baez, 732 F.2d 780, 782 (10th Cir. 1984); United States v. Davila, 698 F.2d 715, 717 (5th Cir. 1983); United States v. Hodges, 566 F.2d 674, 675 (9th Cir. 1977).

For a detailed discussion of the federal offense, see Shannonhouse, Misprision of a Federal Felony: Dangerous Relic or Scourge of Malfeasance?, 4 U. BALT. L. REv. 59 (1974).

41. See State v. Flynn, 100 R.I. 520, 522, 217 A.2d 432, 433 (1966) (offense exists in Rhode Island); State v. Carson, 274 S.C. 316, 318, 262 S.E.2d 918, 920 (1980) (common law offense exists in South Carolina).

42. See, e.g., Holland v. State, 302 So. 2d 806, 810 (Fla. Dist. Ct. App. 1974); Pope v. State, 284 Md. 309, 352, 396 A.2d 1054, 1078 (1979); State v. Young, 7 Ohio App. 2d 194, 200, 220 N.E.2d 146, 151 (1966). Three states-Louisiana, Maine, and New Jersey-that had misprision of felony statutes patterned after the federal statute have repealed them. See reporter's comment to LA. REv. Stat. AnN. § 14:131 (West 1974); ME. Rev. Stat. AnN. tit. 17, § 901 (1964); N.J. Star. AnN. § 2A: 97-2 (West 1969 \& Supp. 1984). In New Jersey, mere failure to report constituted misprision. See State v. Conquest, 152 N.J. Super. 382, 377 A.2d 1239 (1977); State v. Hann, 40 N.J.L. 228 (1878). In Louisiana and Maine, misprision was interpreted as requiring something more than a mere failure to report a felony. See State v. Michaud, 150 Me. 479, 484, 114 A.2d 352, 355 (1955) (must be act of positive concealment); State v. Graham, $190 \mathrm{La} .669,680,182$ So. 711, 714 (1938) (misprision of felony statute equivalent to accessory after the fact offense). Only South Dakota retains such a statute, but it has remained uninterpreted. See S.D. Codified LAws ANN. § 22-11-12 (1979).

43. State v. Wilson, 80 Vt. 249, 67 A. 533 (1907). 
ing to use force to prevent a felony committed in one's presence. ${ }^{44}$ The majority view, however, was that common law misprision of felony at the state level consisted of a failure to report a crime to the authorities plus an additional element - an evil intent ${ }^{45}$ or some positive act. ${ }^{46}$ Decisions interpreting the status of various parties to a crime reflect American courts' reluctance to impose a positive duty to report crime. ${ }^{47}$ For example, the mere passive failure to disclose a crime to the authorities does not make one an accesssory after the fact. ${ }^{48}$ The law requires a positive act of concealment $^{\mathbf{4 0}}$ or some other sort of assistance..$^{50}$ Similarly, a failure to disclose knowledge of a crime, without any other act, will not render one an accomplice to a crime ${ }^{51}$ or an accessory before the fact. ${ }^{62}$ No criminal liability results from failure to report the imminent commission of a crime, ${ }^{\text {bs }}$

44. See Suell v. Derricott, 161 Ala. 259, 272-73, 49 So. 895, 900-01 (1909) (citing Carpenter v. State, 62 Ark. 286, 308, 36 S.W. 900, 906 (1896)).

45. See Commonwealth v. Lopes, 318 Mass. 453, 459, 61 N.E.2d 849, 852 (1945); State v. Wilson, 80 Vt. $249,254,67$ A. 533, 534 (1907).

46. See State v. Carson, 274 S.C. 316, 262 S.E.2d 918 (1980) (defendant deliberately concealed information when questioned by police); $c f$. State v. Biddle, 32 Del. 401, 124 A. 804 (1923) (offense requires willful neglect to prevent felony or prosecute in addition to failure to report); Wren v. Commonwealth, $67 \mathrm{Va} .952,961-62$ (1875) (police officer purposely neglected duty to arrest felon).

47. Note the following dictum from Marbury v. Brooks, 20 U.S. (7 Wheat.) 556, 575-76 (1822): "It may be the duty of a citizen to accuse every offender, and to proclaim every offence which comes to his knowledge; but the law which would punish him in every case for not performing this duty is too harsh for man."

48. See, e.g., Russey \& Way v. State, 257 Ark. 570, 575, 519 S.W.2d 751, 755 (1975); Lowe v. People, 135 Colo. 209, 215, 309 P.2d 601, 604 (1957); Manry v. State, 77 Ga. App. 43, 51, 47 S.E.2d 817, 822 (1948); Maddox v. Commonwealth, 349 S.W.2d 686, 689 (Ky. 1960); State v. Jackson, 344 So.2d 961, 963 (La. 1977); McClain v. State, 10 Md. App. 106, 115, 268 A.2d 572, 576 (1970); State v. Hicks, 22 N.C. App. 554, 557, 207 S.E.2d 318, 320, cert. denied, 285 N.C. 761, 209 S.E.2d 286 (1974); Commonwealth v. Giacobbe, 341 Pa. 187, 195, 19 A.2d 71, 75 (1941).

49. As used in statutes defining liability as an accessory after the fact, the word "conceals" has been interpreted to require an affirmative act. See People v. Garnett, 129 Cal. 364, 366, 61 P. 1114, 1115 (1900); State v. Brown, 197 Neb. 131, 133, 247 N.W.2d 616, 617 (1976); $c$. People v. Stiles, 46 IIl. App. 3d 359, 363, 360 N.E.2d 1217, 1220 (1977) (interpreting concealing of homicidal death statute).

It is not always clear however, exactly what type of action constitutes affirmative concealment for purposes of establishing liability as an accessory after the fact. For example while some courts have held that the giving of false information to the authorities is sufficient, see, e.g., People v. Duffy, 269 Cal. App. 2d 97, 103-04, 74 Cal. Rptr. 606, 609 (1969); State v. Potter, 221 N.C. 153, 156, 19 S.E.2d 257, 259 (1942); Prine v. State, 509 S.W.2d 617, 618 (Tex. Crim. App. 1974), others have taken the opposite view. See, e.g., Farmer v. State, 56 Okla. Crim. 380, 381-82, 40 P.2d 693, 694 (1935); State v. Clifford, 263 Or. 436, 440-41, 502 P.2d 1371, 1374 (1972); Findley v. State, 378 S.W.2d 850, 852-53 (Tex. Crim. App. 1964).

50. See, e.g., James v. State, 351 So. 2d 693, 696 (Ala. Crim. App. 1977); Moore v. State, 94 Ga. App. 210, 211-12, 94 S.E.2d 80, 83-84 (1956); McClain v. State, 10 Md. App. 106, 114-15, 268 A.2d 572, 576 (1970).

51. See, e.g., Stevens v. State, 111 Ark. 299, 303, 163 S.W. 778, 780 (1914); State v. Lewis, 539 S.W.2d 451, 453-54 (Mo. Ct. App. 1975); Commonwealth v. Guild, 111 Pa. Super. 349, 352-53, 170 A. 699, 700 (1934); Miller v. State, 72 S.W. 996 (Tex. Crim. App. 1903).

52. Sams v. Commonwealth, 294 Ky. 393, 398-99, 171 S.W.2d 989, 992 (1943).

53. See, e.g., Dowdle v. Commonwealth, 554 S.W.2d 92, 94 (Ky. Ct. App. 1977); Hightower v. State, 78 Tex. Crim. 606, 607-08, 182 S.W. 492, 493 (1916). 
and there is no obligation to report exculpatory information to the authorities. ${ }^{54}$

\section{Addressing the Problem Through Other Legal Means}

Non-legal means, such as publicity campaigns ${ }^{55}$ and rewards, ${ }^{58}$ have proven insufficient in encouraging crime reporting, perhaps because only those who are already willing to report crimes can be reached by noncoercive measures. ${ }^{57}$ These measures need to be supplemented by more effective means in order to reach a larger segment of the population. Two possibilities would be either the imposition of a duty to rescue in criminal situations, ${ }^{\text {s8 }}$ or the creation of civil penalties for not reporting crimes.

\section{A. Duty to Rescue}

Imposing an affirmative duty to rescue in criminal situations brings with it the dangers of vigilantism and interference with the criminal justice system. The American legal system has long provided for citizen participation in the criminal justice process. ${ }^{58}$ However, in order to guard

54. People v. Dawson, 50 N.Y.2d 311, 316-19, 406 N.E.2d 771, 774-76, 428 N.Y.S.2d 914, 918-19 (1980).

55. See Bickman, Bystander Intervention in a Crime: The Effect of a Mass-Media Campaign, 5 J. Applied Soc. Psychology 296 (1975) (publicity efforts to encourage reporting of shoplifting in college bookstore found ineffective); $c f$. Bickman \& Green, supra note 5, at 7, 12 (signs posted in supermarket to encourage reporting of shoplifting found ineffective). But see Klentz \& Beaman, The Effects of Type of Information and Method of Dissemination on the Reporting of a Shoplifter, $11 \mathrm{~J}$. APPLIED Soc. PSYCHOLOGY 64 (1981) (giving information on crime reporting in lecture format increases reporting rate).

56. See Bickman \& Helwig, Bystander Reporting of a Crime, 17 CRIminology 283, 290 (1979) (rewards ineffective); $c f$. Bickman \& Green, Is Revenge Sweet? The Effect of Attitude Toward a Thief on Crime Reporting, 2 CRIM. JusT. \& BEHAv. 101, 109 (1975) (intangible benefit of retribution against an unpleasant offender does not affect crime reporting).

57. It is unclear how large a segment of the population is indifferent to positive inducements to crime reporting. Some research suggests that many are indifferent to the effectiveness of police in their decision whether to report crime. Bickman, Attitude Toward an Authority and the Reporting of $a$ Crime, 39 Sociometry 76 (1976); Hawkins, Who Called the Cops?: Decisions to Report Criminal Victimization, 7 LAw \& Soc'y REv. 427, 439 (1973). Other research reveals that the young and better educated are less likely to report crime. This has been explained by a lack of commitment to community and a sense of alienation from authority. Blum-West, Calling the Cops: A Study of Why People Report Crimes, 11 J. Police ScI. \& AD. 8, 14 (1983).

58. See supra note 8 and accompanying text. Two states have laws which appear to impose such a duty. See MinN. Stat. ANN. $\$ 604.05$ (West Supp. 1983); VT. Stat. ANN. tit. 12, $\$ 519$ (1973). Both of these statutes make the failure to render reasonable assistance to another exposed to grave physical harm a misdemeanor (when the giving of such assistance can be done with little peril to the onlooker).

Similarly, many of the European civil law countries have long had affirmative duty to rescue laws. See Feldbrugge, Good and Bad Samaritans: A Comparative Survey of Criminal Law Provisions Concerning Failure to Rescue, 14 AM. J. CoMp. L. 630 (1966) (discussing the provisions in numerous European countries); Note, Stalking the Good Samaritan: Communists, Capitalists and the Duty to Rescue, 1976 UTAH L. REv. 529 (comparing American law to that of Soviet Union and Czechoslovakia).

59. See infra notes $106-109$ and accompanying text. 
against vigilante acts, strict limits have been placed on the actions which citizens may take to prevent crime. ${ }^{60}$ Although the provision of information by citizens is essential, the advent of modern police forces has greatly reduced the need for direct citizen participation in the apprehension of criminals $^{61}$ and actions permissible for police, the official guardians of order, are not always available to private citizens. ${ }^{62}$

Mandatory intervention in criminal situations would constitute a retreat from the idea that society's designated agents, the police, should enforce the law, and a movement toward the more primitive notion of self-help. ${ }^{63}$ The dangers of "self-help justice" are especially acute at the apprehension stage, when emotions can distort rational behavior, ${ }^{64}$ and lead to vigilantism. ${ }^{\circ 5}$ Requiring citizens to intervene in criminal emergencies would up-

60. The criminal law regards the use of physical or deadly force by citizens in criminal situations to be excusable, not laudable. A private citizen may use deadly force only to prevent the escape of a violent felon. See Commonwealth v. Chermansky, 430 Pa. 170, 242 A.2d 237 (1968) (citizen convicted of second degree murder for shooting fleeing prowler). Similarly, one may not shoot another who is committing a felony unless there is a fear of bodily injury. See State v. McIntyre, 106 Ariz. 439, 477 P.2d 529 (1970) (defendant convicted of second degree murder for shooting deceased five times to prevent an unarmed assault and battery). Penal provisions which allow citizens to use physical or deadly force to prevent crimes or defend others are usually compiled under sections providing for defenses to criminal liability. See, e.g., DEL. CoDE ANN. tit. 11, § 464 (1979); GA. CoDE ANN. § 16-3-21 (1984); N.Y. Penal Law § 35.15 (McKinney 1975). In Alexander v. State, 52 Md. App. 171, 447 A.2d 880, affd, 294 Md. 600, 451 A.2d 664 (1982) the court, interpreting Maryland's statutory recognition of a defense for third parties intervening in violent assaults, noted that: "[A]n intent to punish the offender or to avenge his victim will not suffice. The purpose of the intervention must have been 'to aid' the victim, or the statutory absolution is lost." Id. at 887 .

These provisions are rightly termed defenses because the acts committed by the citizens would be crimes under other circumstances. Our criminal justice system would be too harsh if it punished reasonable citizens acting in good faith during criminal emergencies. However, there are those who have perverted the meaning of these provisions. The Federation of Greater New York Rifle and Pistol Clubs, for example, has on occasion given \$200 "Courageous Citizen Awards" to individuals who have engaged in armed self-defense, including killing when necessary. See Crim. Control Dig., May 2, 1977 , at 9.

61. In one study of Brooklyn police, the average response time to "crime in progress" calls was less than three minutes. N.Y. Times, Jan. 4. 1976, at 1, col. 5.

62. For example, the Model Penal Code limits the privilege of using deadly force to effectuate an arrest to peace officers and to individuals assisting police officers. MODEL PENAL. CODE $§ 3.072$ (b)ii (Proposed Official Draft 1962).

63. Professor Donald Black suggests that, despite the advanced development of law in modern society, we are not much removed from more primitive cultures where self-help is the dominant means of righting wrongs. Black interprets much of present crime as the result not of irrational or pecuniary motives, but rather the desire to redress wrongs and grievances. Black, Crime as Social Control, 48 AM. Soc. Rev. 34 (1983).

64. An intervening witness might use excessive force or misinterpret the situation entirely, causing more harm than good. Cf. People v. Young, 11 N.Y.2d 274, 183 N.E.2d 319, 229 N.Y.S.2d 1 (1962) (intervening citizen convicted of assault on plainclothes police officer who was attempting to subdue suspect, despite defendant's admitted good faith belief that an assault rather than an arrest was occurring).

65. Historically, those areas of the United States which lacked a sufficient body of law enforcement officers were most prone to outbreaks of vigilante justice. An example is California. Soon after the gold rush of 1849 , California was incorporated as a state of the union. The early California state government failed to establish sufficient order in the mines, or to protect personal property. One consequence was that county sheriffs were often unable to protect accused prisoners from angry lynch mobs. See M. Williams, History of the San Francisco Committee of Vigilance of 1851, at 
set the legal system's delicate balance between necessary private acts and self-help. ${ }^{6 \theta}$ Imposing a duty to rescue in criminal situations gives vigilante justice official approval. ${ }^{67}$

Even that citizen intervention which is not tainted by vigilantism is problematic and costly. Given the lack of full legal redress for those whose rights have been violated by citizen intervenors and the absence of guidelines regulating such intervention, the imposition of a duty to intervene would create many problems for criminal justice officials. The costs of intervention by untrained individuals in a criminal emergency exceed those of intervention in a noncriminal emergency. ${ }^{68}$ The vast majority of citizens have little police training. ${ }^{69}$ In addition to endangering themselves ${ }^{70}$ these intervenors may endanger other bystanders ${ }^{71}$ and impede the course of criminal justice by destroying evidence ${ }^{72}$ or violating the rights of criminal defendants. ${ }^{73}$

Police abuses are kept in check by internal departmental guidelines, ${ }^{74}$

\section{0-51 (1921).}

66. For example, the Model Penal Code does not justify a citizen's mistake as to the lawfulness of the force used in preventing a crime. MOdel Penal Code $\$ 3.09$ (Proposed Official Draft 1962). Mandatory intervention would make this provision especially burdensome; the citizen would be required to intercede yet, at the same time, would be potentially liable for a mistaken course of action.

67. This is not a far-fetched notion. Segments of the population believe that law enforcement should be taken from the criminal justice system, with its due process protections, and placed in the hands of the citizenry. Consider, as one extreme example, the town of Kenneshaw, Georgia, which passed an ordinance requiring the heads of households to own firearms. Police Mag., July 1982, at 4.

68. In noncriminal emergencies-for example, a motor vehicle accident or drowning - the cost of intervention by untrained personnel is usually limited to negligence in the administration of emergency assistance. Most states have Good Samaritan laws, which suggests a prevailing notion that the benefits of intervention by bystanders in noncriminal emergencies outweigh the possible costs in the administration of such assistance. See infra note 101 .

69. In 1983 there were only 645,000 police officers and detectives in the United States. BuREAU of the Census, U.S. DeP'T of Commerce, Statistical abstract of the United States 1985, at 403 (1985).

70. Research suggests that those who directly intervene in criminal situations are more prone to physical confrontation. See Huston, Ruggiero, Conner \& Geis, Bystander Intervention Into Crime: A Study Based on Naturally-Occurring Episodes, 44 Soc. PsychologY Q. 14 (1981) (intervenors found to be more aggressive, physically imposing, and knowledgeable in self-defense: $84 \%$ of sample had been injured); Shotland \& Stebbins, supra note 10, at 524.

71. Police, trained in apprehending criminals, often make mistakes that endanger innocent onlookers. A study of the Chicago Police Department, for example, found that $14 \%$ of police shootings were attributable to accident, stray bullets, or mistaken identification. See Geller \& Karales, Shootings of and by Chicago Police: Uncommon Crises, 72 J. GrIm. L. \& CRminology 1813, 1833 (1981). The use of force by untrained bystanders could bring about a higher rate of unfortunate consequences.

72. But see Burdeau v. McDowell, 256 U.S. 465 (1921) (Fourth Amendment protection against unreasonable searches and seizures does not apply to searches by private individuals).

73. As an extreme example of the potential for abuse of defendant rights when citizens become directly involved in apprehending criminals, consider Commonwealth v. Mahnke, 368 Mass. 662, 335 N.E.2d 660 (1975), cert. denied, 425 U.S. 959 (1976). In Mahnke, a group of "concerned citizens," unhappy with police efforts, abducted a murder suspect, struck the suspect in the head, and transported him to a remote cabin. The citizens questioned the suspect for hours, threatening him with a knife, until he agreed to disclose the location of the victim's body.

74. Internal police directives can sometimes curb police misconduct. For example, after New York City Police Commissioner Patrick Murphy imposed a policy limiting the use of firearms by police, 


\section{Reporting Crime}

disciplinary proceedings ${ }^{75}$ and, in some jurisdictions, civilian review boards. ${ }^{76}$ Even if local governments could create similar control structures for private citizens, ${ }^{77}$ they would be reluctant to do so for fear that such individuals would then be seen as operating under official direction, exposing the municipality to potential liability for citizen excesses. ${ }^{78}$ Futhermore, members of the public whose rights have been infringed by private intervenors would lack the clear legal remedies which protect them against official misconduct. ${ }^{79}$

\section{B. Civil Liability}

Imposing civil liability on witnesses who fail to call the police would not effectively increase crime reporting. It is unlikely that many civil suits would be brought. Most bystanders would be judgment proof, and even if a bystander of sufficient means were sued it would be difficult to prove that the bystander's inaction was the direct cause of the crime victim's

incidents of police shootings declined from 803 to 372 . Crim. Control Dig., Sep. 3, 1979, at 5.

75. The range of disciplinary procedures available to individual police administrators will vary in accordance with the policies of a particular police force and the civil service laws of a particular state. See, e.g., Mont. Code ANN. \$ 44-1-806 (1983) ("If after a hearing the division finds that any charge or charges made against the patrolman are true, it may punish the offending party by a reprimand, suspension without pay, demotion, or discharge.").

76. See Terrill, Complaint Procedures: Variations on the Theme of Civilian Participation, $10 \mathrm{~J}$. Police SCI. \& AD. 398 (1982) (discussing merits and disadvantages of civilian review boards).

77. In People v. Luciani, 120 Misc. 2d 826, 466 N.Y.S.2d 638 (1983), the defendant claimed that his rights had been violated in an unconstitutional seizure by an off-duty auxiliary police officer. Attempting to impose a control structure on citizen anti-crime activities, the court held that citizen groups acting under "governmental supervision" are subject to the same standards of conduct as police. In Luciani, the auxiliary police officer had been off-duty (i.e., out of uniform and not on patrol) and therefore was not considered to be under governmental supervision or subject to the same restrictions as police.

It is unclear how the Luciani "governmental supervision" standard would be applied in other contexts. Would "blockwatchers" be considered to be under governmental supervision? Or tenant patrols? Would these other groups be subject to less rigorous standards of behavior?

78. See Using Auxiliary Policemen Can Be Risky for Cities, 10 CuRrent MuN. ProBs. 432 (1984) (discussing potential municipal liability under 42 U.S.C. $\$ 1983$ that might result from using citizens in auxiliary police roles).

79. Individuals may bring an action under 42 U.S.C. § 1983 against police for deprivations of rights. See Project, Suing the Police in Federal Courts, 88 YALE L.J. 781, 781 n.3 (1979) (noting filing of thousands of such suits in recent years). Additionally, it may be possible to bring suit for constitutional deprivations by police directly under the Constitution. See Bivens v. Six Unknown Named Agents of Fed'I Bureau of Narcotics, 403 U.S. 388 (1971). But see Note, Constitutional Law: Bivens Again, 10 Stetson L. Rev. 329 (1981) (suggesting that Supreme Court restricts Bivens remedy to federal wrongdoing).

Private conduct or wrongs by citizens are not actionable under 42 U.S.C. $\$ 1983$. See Cole v. Smith, 344 F.2d 721 (8th Cir. 1965); Williams v. Yellow Cab Co. of Pittsburgh, Pa., 200 F.2d 302 (3d Cir. 1952), cert. denied, 346 U.S. 840 (1953); Boyd v. Shawnee Mission Pub. Schools, 522 F. Supp. 1115 (D. Kan. 1981); Adkins v. Adkins, 459 F. Supp. 406 (S.D. W. Va. 1978); Ehn v. Price, 372 F. Supp. 151 (N.D. Ill. 1974); Elders v. Consol. Freightways Corp. of Delaware, 289 F. Supp. 630 (D. Minn. 1968).

Similarly, a defendant's private status precludes Bivens liability. Zerilli v. Evening News Ass'n, 628 F.2d 217, 224 (D.C. Cir. 1980). 
damages. ${ }^{80}$ In addition to being inadequately enforced, a civil statute would lack the moral strength of a criminal statute and would therefore be less successful in changing people's attitudes toward performing a prescribed behavior. Criminal liability makes conduct more imperative, more clearly reflects society's collective values, ${ }^{81}$ and more effectively educates the public as to appropriate standards of conduct..$^{\mathbf{2 2}}$ Finally, civil liability remedies only the individual wrong a crime victim suffers. It fails to account for the wrong society suffers when a crime goes unreported. ${ }^{\mathbf{s s}}$

A criminal statute is much better suited for the task of increasing crime reporting. The ultimate purpose of a criminal statute is to direct individuals toward socially acceptable forms of behavior. This is accomplished through both the deterrent effect of the imposition of sanctions, ${ }^{84}$ and the moral force of criminal law. ${ }^{85}$ The very existence of a criminal statute, even an unpopular one, may compel obedience by virtue of the respect most people have for the institution of law. ${ }^{88}$ The criminal law can be used to encourage a positive form of behavior or to reduce a negative one. Other criminal statutes seeking to impose positive conduct have significantly increased the desired behavior. Most significant here are the results of one study which found that a mandatory child abuse reporting law ${ }^{87}$ produced a significant permanent increase in the reporting of child

80. Compare the use of criminal sanctions where the risks and costs of enforcement are borne by the state. See Ball \& Friedman, The Use of Criminal Sanctions in the Enforcement of Economic Legislation: A Sociological View, 17 STAN. L. REv. 197, 211-13 (1965) (discussing advantage of criminal sanctions over civil enforcement in achieving social goals).

81. A criminal statute must be passed by a legislature elected by the populace. Civil liability can be created through judge-made common law which represents public opinion less directly than does a legislative enactment.

82. One survey found that in West Germany, where a duty-to-rescue statute exists, $86 \%$ of the interviewees realized that there was such a legal duty. In the United States, which at the time had no such statute, only $19 \%$ believed there was such a legal duty. Zeisel, An International Experiment on the Effects of a Good Samaritan Law, in THE Good SAMARITAN AND THE LAw 209, 210 (J. Ratcliffe ed. 1966).

83. See D'Amato, The "Bad Samaritan" Paradigm, 70 Nw. U.L. REv. 798, 807 (1975) (discussing how crime injures public as well as individual victims).

84. See generally F. Zimring \& G. Hawkins, DeterRence: The Legal Threat in Crime CoNrRol (1973) (discussing rationale, effect and research into use of deterrence in curbing misconduct).

85. The more prevalent view concerning the relationship between law and morality is that of H.L.A. Hart, who asserted that law is a reflection of morality. See H.L.A. HART, THE ConCEPT of LAw 199-200 (1961). But even Hart accepted the possibility that law could influence morality in the first instance, as well as reflect it. See H.L.A. HART, LAw, LIBERTY, AND MORALITY 1-2 (1966).

86. See Ball \& Friedman, supra note 80 , at 217 ("The very fact that a criminal statute has been enacted by the legislature is a powerful factor in making the proscribed conduct illegitimate in the eyes of a potential actor, even when the actor disagrees with the purpose of the law." ); Fuller, Morals and the Criminal Law, 32 J. CRIM. L. \& CRIMINology 624, 629 (1942) ("[E]ven in the instance of a very unpopular law, people are likely to observe it for some time after its passage simply because it is the law of the land."); H.L.A. HART, THE CONCEPT OF LAw, supra note 85, at 198 ("[V]ast numbers [may] be coerced by laws which they do not regard as morally binding.").

87. See infra note 111 . 
abuse..$^{88}$ Seat belt laws, ${ }^{80}$ motorcycle helmet laws, ${ }^{90}$ draft registration, ${ }^{91}$ and the so-called "pooper-scooper law,"92 are other cases in point.

\section{Imposing a Duty to Report CRime}

\section{A. The Proposal}

This Note is concerned only with the problems presented by witnesses ignoring crime; its proposal is designed to combat such bystander apathy. American courts have recognized that one of the duties of citizenship is to report crime. ${ }^{88}$ Yet a mere failure to report a crime to the authorities is rarely, if ever, considered a crime in itself. ${ }^{94}$

Although it is still the general rule that failure to report a crime is neither a criminal offense nor the violation of a positive duty, there has been a trend away from this rule. For example, the law has moved toward imposing a positive duty to report crime upon those in public service, ${ }^{95}$ those in an especially strong position to know of certain crimes, ${ }^{96}$ or those knowing of a particularly dangerous crime. ${ }^{97}$ There has also been some

88. Sawyer \& Money, Legal Reform in Child Abuse Reporting, 5 Evaluation Rev. 758, 777 (1981).

89. Compliance with New York's mandatory seat-belt law exceeds $60 \%$. N.Y. Times, Feb. 28, 1985, at B1, col. 1.

90. Following the recision of federal highway fund penalties for those states which did not have mandatory motorcycle helmet laws in 1976, 26 states repealed their helmet laws. As a result, motorcycle helmet usage declined approximately $50 \%$, and the mortality rate of motorcyclists rose $38 \%$. Watson, Zador \& Wilks, The Repeal of Helmet Use Laws and Increased Motorcyclist Mortality in the United States, 1975-1978, 70 AM. J. PuB. HeAlTH 579, 582-83 (1980).

91. Despite the limited number of criminal prosecutions, compliance with Selective Service Registration stood at $94.2 \%$ as of 1982 . N.Y. Times, Oct. 5, 1982, at 14, col. 2.

92. See N.Y. Times, Aug. 2, 1979, at B3, col. 3 (noticeable feeling of compliance with pooperscooper law).

93. See Miranda v. Arizona, 384 U.S. 436, 477-78 (1966) ("It is an act of responsible citizenship for individuals to give whatever information they may have to aid in law enforcement.") State courts have echoed this sentiment. See, e.g., People v. Ford, 234 Cal. App. 2d 480, 487-88, 44 Cal. Rptr. 556, 559-60 (1965); Pcople v. Austin, 108 Misc. 2d 829, 837, 438 N.Y.S.2d 908, 914 (1981); State v. Grimmett, 54 N.C. App. 494, 498, 284 S.E.2d 144, 148 (1981), petition denied, appeal dismissed, 305 N.C. 304,290 S.E.2d 706 (1982).

94. In People v. Donelson, 45 Ill. App. 3d 609, 611, 359 N.E.2d 1225, 1227 (1977), the court commented: "Our attention has not been called to a single case in any American jurisdiction directly holding that a person commits an offense by merely remaining silent as to the commission of an offense."

95. See, e.g., D.C. CoDE ANN. § 4-175 (1981) (criminal offense for member of police force to withhold information relating to crime); ILL. ANN. STAT. ch. 38, § 33-2 (Smith-Hurd Supp. 1984) (misdemeanor for public officer or juror to fail to report bribe); Miss. CODE ANN. \$ 97-11-35 (1973) (criminal offense for peace officer willfully to absent himself from scene of impending crime in order to avoid knowledge of it).

96. See, e.g., Commonwealth v. Friedman, 193 Pa. Super. 640, 644-46, 165 A.2d 678, 681 (1960) (baseball pitcher had duty to report attempted bribery of athletic contest); Weber v. Western Bank, 336 N.W.2d 652, 653 (S.D. 1983) (supermarket required to turn over possibly fraudulent checks); D.C. CoDE ANN. § 4-175 (1981) (private detective must not withhold information about crime); N.Y. PeNAl LAw § 250.35 (McKinney 1980) (misdemeanor for telephone company employees to fail to report criminal communications).

97. See Neb. Rev. Stat. $\S 28-1226$ (1979) (misdemeanor for owner to fail to report theft of 
movement toward imposing an obligation to report crimes upon the general population. The vast majority of states have compounding-of-felony statutes, which make it a crime for an individual to receive consideration for not reporting an offense to the authorities. ${ }^{98}$

This Note proposes that the problem of bystander failure to report crime be addressed by making it a misdemeanor ${ }^{90}$ for a felony witness to fail to report the crime to the appropriate authorities. ${ }^{100}$ By limiting its application to those persons who have actually witnessed a felony, the proposed statute avoids the potential for overbroad coverage. At the same time, the proposed statute avoids too limited a scope by providing for the reporting of all types of felonies, rather than just those of violence. Problems of notice are avoided by limiting the reporting obligation to those felonies that are "of such a nature that a reasonable person in the same circumstances would know it to be a serious offense."

A high standard of proof could ensure that only cases where there is a strong probability of guilt would be prosecuted. Those who are unable to report because of infirmities, for example, the aged, handicapped, or ill, would have an affirmative defense, as would those who are not competent to report, such as the young, the insane, and those who would incriminate themselves by reporting.

explosives).

98. See generally Note, Compounding Crimes: Time For Enforcement, 27 Hastings L.J. 175 - (1975) (collecting all compounding statutes and discussing their use).

99. Although nonreporting of crime is a serious problem, imposing only a limited penalty is essential to the success of a novel statute that proposes to alter traditional modes of behavior. Police, prosecutors, and judges would be unwilling to enforce a statute that placed new and unfamiliar demands on the public if the penalty is unduly severe; thus, too severe a law would in effect become nullified.

This Note proposes an initial statute bearing a small sanction. After a period of time, it is hoped that the public will not only accept the statute but demand stricter enforcement and higher penalties.

An example of this pattern can be seen in the development of drunk-driving laws. In the recent past, juries were reluctant to convict drunk drivers for their first offense. See Brocder, The University of Chicago Jury Project, 38 NEB. L. REv. 744, 750 (1959). Today, with the advent of such groups as MADD (Mothers Against Drunk Drivers), drunk driving has become an issue of major public concern, resulting in increased enforcement efforts, see Note, Curbing The Drunk. Driver Under the Fourth Amendment: The Constitutionality of Roadblock Seizures, 71 GEo. L.J. 1457 (1983), and the enactment of stiffer penalties, see Winter, States Get Tougher on Drunk Drivers, 68 A.B.A. J. 140 (1982).

100. The proposed statute reads:

It is the duty of all citizens to report crimes to the police. Anyone who has witnessed a felony shall report it to the police or other appropriate law enforcement body as soon as is reasonably possible, provided that the person is placed in no danger by so reporting and a convenient means of reporting is available. A failure to report a felony within a reasonable time is a violation of this statute and thus a petty misdemeanor. For the purposes of this statute, "felony" shall mean any crime which is punishable by more than one year in prison and of such a nature that a reasonable person in the same circumstances would know it to be a serious offense. This includes, but is not limited to, Murder, Robbery, Rape, Assault and Battery, Burglary, and Auto Theft in all their degrees. 


\section{B. Placing Mandatory Crime Reporting in the Current Social-Legal Structure}

There has been a general trend in American law of encouraging people to help one another in civil contexts. Good samaritan statutes, ${ }^{101}$ state statutes requiring motorists involved in traffic accidents to render assistance to injured parties, ${ }^{102}$ and the efforts of some states to compensate citizens for aid rendered in emergencies ${ }^{\mathbf{1 0 3}}$ are cases in point. As discussed earlier, ${ }^{104}$ the imposition of an affirmative duty of intervention in criminal contexts would be inappropriate. Mandatory crime reporting is more in accord with current obligations imposed on citizens in criminal contexts and it addresses the roots of underreporting.

The control of criminality is a societal responsibility shared by all. ${ }^{105}$ In accordance with this shared responsibility, society requires citizens to participate in the criminal justice process when called upon to do so, ${ }^{108}$ to be witnesses at criminal trials, ${ }^{107}$ to be members of juries, ${ }^{108}$ and to cooperate at the intake point of the criminal justice process. ${ }^{109}$ Citizens already have

101. In the past, the majority of good samaritan statutes were aimed solely at the medical profession and typically immunized doctors and other medical personnel from civil liability for any negligence during the administration of emergency care. See Note, The Duty to Aid One in Peril: Good Samaritan Laws, 15 How. L.J. 672, 677-78 (1969). Today, the vast majority of states have statutes which immunize anyone from civil liability for negligence in the rendering of assistance during emergencies. See, e.g., Fra. Stat. ANN. § 768.13 (1984); Iowa Code ANN. § 613.17 (West Supp. 1984); N.H. Rev. STAt. ANN. $\S 508.12$ (1983).

102. See, e.g., Colo. Rev. Stat. § 42-4-1403 (1984); Miss. Code ANN. § 63-3-405 (Supp. 1983); N.D. Cent. Code § 39-08-06 (1980); Utah Code ANN. § 41-6-31 (Supp. 1983).

103. Some states have established special funds and claims procedures to compensate citizens who are injured while giving assistance during an emergency. See, e.g., CAL. Gov't CODE $\S 13970$ (West 1980); OKLA. Stat. ANN. tit. 76, §5.4 (West Supp. 1984).

104. See supra part III A.

105. See Roberts v. United States, 445 U.S. 552 (1980) (convicted felon, like any other citizen, has responsibility to cooperate with law enforcement authorities); United States v. Nixon, 418 U.S. 683 (1974) (criminal justice system's need for evidence overrides even interests of President of United States).

106. The obligation to assist in the criminal justice process is so strong that it outweighs other fundamental societal values. For example, a news reporter has no First Amendment privilege to decline to aid a grand jury's investigation of criminality. Branzburg v. Hayes, 408 U.S. 665, 697 (1972). Similarly, a witness may be compelled to testify at a criminal trial despite sincere religious objections, People v. Woodruff, 26 A.D.2d 236, 238, 272 N.Y.S.2d 786, 789 (1966), appeal dismissed, 20 N.Y.2d 879, 232 N.E.2d 652, 285 N.Y.S.2d 622 (1967), affd, 21 N.Y.2d 848, 236 N.E.2d 159, 288 N.Y.S.2d 1004 (1968), or genuine fear for the safety of herself or her family, People v. Carradine, 52 IIl. 2d 231, 287 N.E.2d 670 (1972).

107. Our courts may go so far as to subpoena an American citizen living in a foreign country and require his return in order to testify at a criminal trial. See Blackmer v. United States, 284 U.S. 421, 438 (1932) ("It is also beyond controversy that one of the duties which the citizen owes to his government is to support the administration of justice by attending its courts and giving his testimony whenever he is properly summoned."). A witness who refuses to testify can be summarily confined. 28 U.S.C.A. $\S 1826$ (West Supp. 1984).

108. Fines can be imposed on those who fail to perform their jury obligations. See, e.g., CAl. Crv. Proc. Code $\$ 238$ (West Supp. 1985); Ill. ANN. STAT. ch. 78, §15 (Smith-Hurd Supp. 1984); N.J. Stat. ANN. \& 2A:79-1 (West 1976).

109. Many states require citizens to assist a peace officer in making an arrest when such an 
many obligations to report information to the authorities. Virtually every state requires the reporting of traffic accidents ${ }^{110}$ and child abuse. ${ }^{111}$ Legislatures have also required the reporting of a wide variety of other occurrences. ${ }^{112}$ Mandatory crime reporting is consistent with these duties.

Although, like any other human behavior, crime reporting may be influenced by a host of variables, ${ }^{113}$ mandatory crime reporting would be effective in responding to the main social-psychological factors that lead to underreporting. Research has shown that it is possible to instill a sense of personal responsibility in bystanders to help prevent crime. ${ }^{114}$ By inform-

officer so commands. See, e.g., Cal. Penal. Code $\S 150$ (West Supp. 1985); N.Y. Penal Law $\S$ 195.10 (McKinney Supp. 1984); Ohio Rev. Code ANn. $\S 2921.23$ (Page 1982); Wis. Stat. ANn. $\S$ 946.40 (West 1982).

110. States require the immediate notification of the police or the filing of a written report with the appropriate motor vehicle authorities following any traffic accident that results in injury or more than a minimal amount of property damage. See, e.g., CAL. VeH. CodE $\S 20002$ (West Supp. 1985); ConN. Gen. Stat. § 14-108 (1983); Ill. ANN. STAT. ch. 951/2, \& 11-406 (Smith-Hurd Supp. 1984); N.Y. VEH. \& TRAF. LAW § 605 (McKinney Supp. 1984).

The Oregon statute, OR. REv. STAT. $\S 483.602$ (1981), is especially interesting. It requires both the drivers, and any witness to an accident to leave their name and address with the driver or occupant of vehicles involved in an accident.

111. Virtually every state has passed some sort of child protection act which requires reporting of suspected incidents of child abuse to the appropriate authorities. Most of these statutes apply only to those directly involved in child care, such as teachers, social workers, doctors, and nurses. Failure to report in many cases results in criminal penalties. See, e.g., CAL. Penal Code $\$ 11166$ (West Supp. 1985); Ill. ANn. Stat. ch. 23, § 2054 (Smith-Hurd Supp. 1984); N.Y. Soc. Serv. Law $\S 413$ (McKinney 1983). A significant minority of states have passed statutes that impose a duty of mandatory reporting on any person who has reason to suspect that a child is being neglected or abused. See, e.g., DEL. CodE ANN. tit. 16, § 903 (1983); IdAHo Code § 16-1619 (Supp. 1984); N.J. STAT. ANN. $\$ 9: 6-8.10$ (West 1976). For a complete listing of the various child abuse reporting statutes see Note, Compounding Crimes: Time for Enforcement, 27 Hastings L.J. 175, 184-87, $\mathrm{nn} .60-67$ (1975). It is somewhat curious that a large number of states have mandated citizen reporting in an area as ambiguous as child abuse and yet have ignored requiring the reporting of felonies.

112. Several states require a waiver of the physician-patient privilege and mandate reporting the treatment of gunshot or knife wounds. Failure to report such incidents may subject the physician or patient to criminal penalties. See, e.g., ARK. Stat. AnN. § 42-501 (1977); Kan. STat. AnN. § 214213 (1981); ME. Rev. Stat. ANn. tit. 17A, $\S 512$ (West 1983); PA. Stat. ANN. tit. 18, $\$ 5106$ (Purdon 1983). Garage owners in some states are required to report any bullet damage they find in automobiles. See, e.g., R.I. GEN. LAws § 31-26-12 (1982). Finally, some jurisdictions impose a general duty on all citizens to report any unusual deaths of which they become aware. See New York City, N.Y. ADMIN. Code ch. 39, § 878-1.0 (1977).

113. The characteristics of the crime observed may affect the reporting rate. $C f$. Borofsky, Stollak \& Messé, Sex Differences in Bystander Reactions to Physical Assault, 7 J. ExPERIMENTal Soc. Psychology 313 (1971) (males inclined to ignore physical assault upon female by male). The individual personalities and characteristics of bystanders will also affect reporting. Gelfand, supra note 29 , at 284-85 (persons with rural upbringing more likely to report crime). Similarly, the characteristics of the victim will influence reporting. See Bleda, Bleda, Byrne \& White, supra note 27, at 13 (crimes against corporate victims less likely to be reported); Gelfand, supra note 29, at 283. Prejudices may also play a role. See Bleda, Bleda \& White, Bystander Reactions to a Petty Crime, 14 CrIMINology 287, 288 (1976) (women more likely to report and be reported); Dertke, Penner \& Ulrich, supra note 5, at 217 (whites more likely to report blacks than other whites). Stereotypes may influence crime reporting as well. See Steffensmeier \& Terry, Deviance and Respectability: An Observational Study of Reactions to Shoplifting, 51 SOc. FORCES 417, 422-23 (1973) (bystanders more likely to report those dressed as "hippies"). But see Gelfand, supra note 29, at 282 ("hippies" not reported at higher rate).

114. Experiments in which a bystander is asked to watch a stranger's belongings illustrate this 
ing the public that it is everyone's personal legal duty to report crime, the proposed statute will counter the effects of diffusion of responsibility.

Mandatory crime reporting can also serve as a substitute for, or a supplement to, ${ }^{115}$ the social influence that traditionally came from sources such as the community, family, and religion. By making the failure to report crime a criminal offense, the proposal combats indecision through its provision of an accepted course of action and its explicit determination that a decision to ignore crime is wrong and socially unacceptable. Finally, for those who engage in a cost-benefit analysis prior to reporting a crime, the possibility of a criminal sanction would tilt the balance in favor of reporting.

Three states, Ohio, Massachusetts, and Washington, have enacted statutes similar to the model proposed in this Note. ${ }^{116}$ Unfortunately, all three are plagued with serious defects as presently drafted.

Ohio has enacted a statute the pertinent part of which states: "No person, knowing that a felony has been or is being committed, shall knowingly fail to report such information to law enforcement authorities."117

As presently drafted the Ohio statute presents problems of being overly broad and vague. The failure to define "knowledge" leaves open the possibility that persons with only second-hand information concerning a crime, or perhaps with only mere rumor or suspicion of a crime, may be under an obligation to report. The one reported case involving this statute resulted in acquittal and severely narrowed the statute's scope. ${ }^{118}$

Massachusetts and Washington have avoided the problems of the Ohio statute by requiring first-hand knowledge of a crime before imposing an obligation to report. Massachusetts imposes an affirmative reporting obligation upon those who know that another person is the victim of one of a specific group of violent felonies listed in the statute and are "at the scene of said crime."118 Washington requires reporting by those who have "wit-

phenomenon. After acceptance of such a commitment, the rate of intervention significantly increased when a subsequent staged theft occurred. See Harrell \& Goltz, Effect of Victim's Need and Previous Accusation of Theft Upon Bystander's Reaction to Theft, 112 J. Soc. Psycholocy 41 (1980); Moriarty, supra note 10, at 373; Shaffer, Rogel \& Hendrick, supra note 12, at 308.

115. Cf. R. Pound, Social Control Throvgh Law 18-25 (1942) (discussing how law has supplanted religion, community, and family as primary means of social control).

116. Also of note is Colorado's recently enacted statute which grants immunity from civil liability to any person or corporation who in good faith reports a crime. See CoLo. REv. STAT. $\$ 18-8-115$ (Supp. 1984).

117. Orro Rev. Code ANN. $\$ 2921.22$ (Page 1982). The statute also contains a detailed list of qualifications to this duty intended to protect privileged relationships such as those between doctor and patient, and clergyman and parishioner.

118. In re Stichtenoth, 67 Ohio App. 2d 108, 425 N.E.2d 957 (1980) (holding that statute did not require direct reporting to police as long as events occur which result in notification of authorities).

119. Mass. GEN. LAws ANN. ch. 268, § 40 (West Supp. 1985) ("Whoever knows that another person is a victim of aggravated rape, rape, murder, manslaughter or armed robbery and is at the scene of said crime shall, to the extent that said person can do so without danger or peril to himself or 
nessed the actual commission of a felony involving violence or threat of violence." ${ }^{120}$ Although these provisions are in keeping with the basic arguments of this Note, they are too narrowly drawn. As both of these statutes are restricted to violent crimes, such important categories of crime as burglary or auto theft are not within their ambit.

\section{Problems of Mandatory Crime Reporting}

A statute requiring witnesses to report crimes is not without potential costs. The statute's benefits, however, far outweigh its potential disadvantages.

\section{Concern about Breaches of Privilege}

When discussing an affirmative duty to report crime, one must consider the effect of such a statute on the confidentiality of privileged communications, such as those between doctor and patient, lawyer and client, and priest and parishioner. The proposed statute does not change the status of these relationships.

By its terms, the statute applies only to those who actually witness a felony and would thus rarely affect these confidential relationships. In those few situations where, for example, a doctor actually witnessed a patient's felony, the statute should apply. These professionals have a duty to protect society against crime and thus do not have a right to conceal information about criminality. ${ }^{121}$ States which recognize evidentiary privileges for such relationships could still honor them and be consistent with the proposed statute.

\section{Selectivity of Enforcement}

The criminal offense of failure to report a felony would be difficult to detect, and a large number of violators would go unpunished. Those apprehended and prosecuted would in all likelihood be guilty of the most

others, report said crime to an appropriate law enforcement official as soon as reasonably practicable. Any person who violates this section shall be punished by a fine of not less than five hundred nor more than two thousand and five hundred dollars.").

120. WaSh. Rev. Code ANN. $\$ 9.69 .100$ (1977) ("Whoever, having witnessed the actual commission of a felony involving violence or threat of violence or having witnessed preparations for the commission of a felony involving violence or threat of violence, does not as soon as reasonably possible make known his knowledge of such to the prosecuting attorney, police, or other public officials of the state of Washington having jurisdiction over the matter, shall be guilty of a gross misdemeanor: Provided, That nothing in this act shall be so construed to affect existing privileged relationships as provided by law.") (emphasis in original).

121. For example, there have been cases holding that a psychiatrist must wam potential victims of criminal acts planned by their patients. See Tarasoff v. Regents of Univ. of California, $17 \mathrm{Cal}$. 3d 425, 551 P.2d 334, 131 Gal. Rptr. 14, (1976); Mavroudis v. Superior Court, 102 Cal. App. 3d 594, 162 Cal. Rptr. 724 (1981); McIntosh v. Milano, 168 N.J. Super. 466, 403 A.2d 500 (1979). 
egregious violations brought to the attention of the police by members of the public. ${ }^{122}$ The possibility of selective enforcement, however, should not bar the enactment of a statute unless it is constructed so as to require facially impermissible discrimination. ${ }^{123}$ The conscious exercise of some selectivity in enforcement is not a constitutional violation. ${ }^{124}$ The government may choose to prosecute only the most egregious violators, ${ }^{125}$ or the public protesters against a law, ${ }^{126}$ as a means of ensuring compliance. The government does not have to seek out violators, but may instead prosecute only those who are made known to it. ${ }^{127}$ Selective enforcement is unconstitutional only if the defendant successfully proves that: 1) others similarly situated were not subjected to enforcement, and 2) the selection of the defendant was based on invidious discrimination (race or religion) or in retaliation for the exercise of constitutional rights. ${ }^{128}$

\section{Retaliation Against Those Who Report}

Although physical reprisal against citizens for reporting crime is probably rare, ${ }^{128}$ there would no doubt be cases where forcing a citizen to come forward would place him or her in physical danger. In theory, such cases should not be problematic, as it is in the interest of the police and prosecutors to do their utmost to protect those who report, in order to encourage compliance with the statute. If this is not sufficient incentive, there is also some precedent for a common law right of action against a municipality for negligently failing to protect citizens who provide information on criminality. ${ }^{130}$ In practice, however, a lack of resources may

122. Any criminal statute has the potential to be abused. However, while this is a caution to observe police behavior, it does not justify failure to enact a statute that serves a valid purpose. There are substantial checks on police misconduct. See supra text accompanying notes 74-76. Lawsuits against police by civil rights activists may be particularly effective. See McCoy, Enforcement Workshop Lawsuits Against Police-What Impact Do They Really Have?, 20 CRIM. L. BuLL. 49 (1984) (suits against police found to have significant deterrent effect on police misconduct).

123. An example would be a law criminalizing the exercise of a particular religion.

124. Oyler v. Boles, 368 U.S. 448 (1962).

125. Cook v. City of Price, Carbon City, Utah, 566 F.2d 699, 701 (10th Cir. 1977); Barton v. Malley, 626 F.2d 151, 155 (10th Cir. 1980).

126. United States v. Martin, 557 F. Supp. 681, 687-88 (N.D. Iowa 1982) (draft registration protester), rev'd on other grounds, 733 F.2d 1309 (8th Cir. 1984); United States v. Tibbetts, 646 F.2d 193, 195 (5th Cir. 1981) (tax protester).

127. See Wayte v. United States, 105 S.Ct. 1524 (1985) (upholding use of passive enforcement in draft registration cases). The fact that a criminal statute is routinely violated is no defense to a prosecution. United States v. Caldwell, 544 F.2d 691, 696 (4th Cir. 1976); United States v. Standefer, 452 F. Supp. 1178, 1188 (W.D. Pa. 1978), affd, 610 F.2d 1076 (3rd Cir. 1979), affd 447 U.S. 10 (1980).

128. United States v. Moon, 718 F.2d 1210, 1229-30 (2nd Cir. 1983), cert. denied 104 S.Ct. 2344 (1984); United States v. Tibbetts, 646 F.2d 193, 195 (5th Cir. 1981); Barton v. Malley, 626 F.2d 151, 155 (10th Cir. 1980); United States v. Martin, 557 F. Supp. 681, 687 (N.D. Iowa 1982), rev'd on other grounds, 733 F.2d 1309 (8th Cir. 1984).

129. See supra note 30 .

130. See Schuster v. City of New York, 5 N.Y.2d 75, 154 N.E.2d 534, 180 N.Y.S.2d 265 (1958), 
result in instances of neglect by the authorities. The ultimate success of the proposed statute depends on members of the public having confidence in the ability of the criminal justice system to provide for their safety when coming forward with information on criminality. Thus, the proposal is only the first step; it must be accompanied by a level of effort and resources on the part of law enforcement agencies that is sufficient to dispel any fears for personal safety when reporting felonies.

\section{GoNCLUSION}

This Note has demonstrated the utility of mandatory witness crime reporting for combatting the national problem of failure to report crime. Mandatory crime reporting reaches the psychological and sociological causes of this phenomenon and would teach the public the correct course of action when confronted with a criminal emergency. Consequently, the proposed statute would serve as a moral impetus for desirable social behavior, while avoiding the vigilante justice that might accompany imposition of a duty to rescue in criminal situations.

-Jack Wenik

in which the court held: "[T] public . . . owes a special duty to use reasonable care for the protection of persons who have collaborated with it in the arrest or prosecution of criminals, once it reasonably appears that they are in danger due to their collaboration." Id. at 269. 